\title{
Current variability by wave propagation in Todos Santos Bay, Baja California, Mexico
}

\section{Variabilidad de corrientes por propagación de ondas en bahía de Todos Santos, Baja California, México}

\author{
Efrain Mateos $^{1 *}$, Silvio Guido Marinone ${ }^{2}$ \\ ${ }^{1}$ IMTA Instituto Mexicano de Tecnología del Agua \\ ${ }^{2}$ Centro de Investigación Cienctifica y de Educación Superior de Ensenada \\ * Corresponding author. E-mail: efrain_mateos@tlaloc.imta.mx
}

\begin{abstract}
The temperature, velocity, and sea level fields for a summer climatological month (August) were analyzed using tridimensional and baroclinic model outputs in Todos Santos Bay (TSB), Baja California, Mexico. The numerical model was forced with wind (nonstationary), heat flux, and California Current System climatology on the open boundary. The 3- to 5-day current variability is related to a baroclinic wave traveling towards the northwest of the bay. Wave travel periodicity was due to the release of accumulated water from the Ensenada-Punta Banda Estuary (E-PBE) region. Local wind stress causes southeastward water flow and, given the TSB geometry, water accumulates in the E-PBE region. Weakening wind stress was the main cause of water release. In addition, complex empirical orthogonal function analysis found that outer TSB disturbances cause sea level variability.
\end{abstract}

Key words: Todos Santos Bay, subinertial wave travel.

RESUMEN. A partir de las salidas de un modelo tridimensional y baroclínico, se analizaron los campos de temperatura, velocidad y superficie libre del mar para un mes climatológico de verano (agosto) en la bahía de Todos Santos (BTS), Baja California, México. El modelo numérico se forzó con viento (no estacionario), flujos de calor y en las fronteras abiertas con climatología que incluyó al Sistema de la Corriente de California. Se encontró que la variabilidad, de 3 a 5 días, del campo de velocidad está relacionado con la propagación, hacia el noroeste de la bahía, de una onda baroclínica. La periodicidad de la propagación de la onda se debió a la liberación de agua acumulada en la región entre Ensenada y el estero de Punta Banda (E-EPB). Se encontró que el esfuerzo del viento local es la causa del transporte de agua hacia el sureste, y debido a la geometría de la BTS, el agua se acumula en la región E-EPB. La relajación del esfuerzo del viento fue la principal causa de la liberación de agua acumulada. A partir del análisis de funciones empíricas ortogonales complejas, se encontró que también las perturbaciones provenientes del exterior de la BTS causan variabilidad en la superficie libre del mar.

Palabras clave: bahía de Todos Santos, propagación de ondas subinerciales.

\section{INTRODUCTION}

Todos Santos Bay (TSB) is a small bay located $100 \mathrm{~km}$ south of the United States-Mexico border (Fig. 1). This bay has 2 mouths that connect it with the Pacific Ocean. The northeastern mouth, between Todos Santos Island (TSI) and San Miguel, is approximately $10 \mathrm{~km}$ wide, whereas the southwestern mouth measures $\sim 5 \mathrm{~km}$. Previous studies suggest that the general circulation in TSB is primarily due to the California Current System, wind stress, and tidal forcing (Gavidia 1988, Argote-Espinoza et al. 1991, Mateos et al. 2009, Flores-Vidal et al. 2015). This study does not include tidal forcing.

\section{The California Current System}

The California Current System (CCS) is formed by the equatorward California Current (CC), the seasonal surface coastal current (SCC), and northward subsurface

\section{INTRODUCCIÓN}

La bahía de Todos Santos (BTS) es una bahía pequeña localizada a $100 \mathrm{~km}$ al sur de la frontera de México con los Estados Unidos de América (Fig. 1). La BTS tiene 2 bocas que conectan con el océano Pacífico. La boca noroeste, entre la isla de Todos Santos (ITS) y San Miguel, tiene una longitud aproximada de $10 \mathrm{~km}$, mientras que la boca suroeste mide $\sim 5 \mathrm{~km}$. Estudios previos sugieren que la circulación general de la BTS se debe principalmente al Sistema de la Corriente de California y al esfuerzo del viento y de la marea (Gavidia 1988, Argote-Espinoza et al. 1991, Mateos et al. 2009, Flores-Vidal et al. 2015). En este estudio, no se incluye el forzamiento de la marea.

\section{El Sistema de la Corriente de California}

El Sistema de la Corriente de California (SCC) lo conforman la corriente de California (CC) con dirección hacia el 
countercurrent (SSC) (Lynn and Simpson 1987). The CC is the eastern part of the anticyclonic gyre in the North Pacific, which is characterized by its shallowness $(0-300 \mathrm{~m})$. This current transports cool, less saline waters with high dissolved oxygen levels from the polar regions to the equatorial zone. The average CC velocity is typically less than $25 \mathrm{~cm} \cdot \mathrm{s}^{-1}$ (Reid and Schwartzlose 1962).

Geostrophic studies (Lynn and Simpson 1987, Strub and James 2000) showed that during spring and summer SCC flows towards the equator off California and the northern Baja California Peninsula (from $30^{\circ} \mathrm{N}$ ). During autumn and winter, SCC is inverted near the coast. By contrast, SSC flows northward at velocities between 4 and $8 \mathrm{~cm} \cdot \mathrm{s}^{-1}$ at $\sim 200 \mathrm{~m}$ depth during most of the year (Barton and Argote 1980). The formation of SCC is attributed to multiple local upwelling fronts (Strub and James 2000). Numeric studies showed that in order to develop velocity cores for SCC and SSC, the meridional variability of the Coriolis parameter $f(\beta$ plane) and the alongshore component of wind stress need to be estimated. The $\beta$ effect allows the offshore propagation of free waves (e.g., Rossby waves), modifying the density structure and contributing to the formation of an alongshore pressure gradient that contributes to the development of SSC along the eastern boundary (Batten 1997). Off the northern Baja California coast, between $31^{\circ} \mathrm{N}$ and $32^{\circ} \mathrm{N}$, the SCC and SSC are unstable and cause great variability in the region (Mateos et al. 2013). Variability in water circulation off the northern Baja California coast has an impact on water circulation variability in TSB (Mateos et al. 2009).

\section{Atmosphere}

There are 2 relevant systems acting together that regulate wind seasonality along the California and Baja California coasts. The first is a high-pressure center located in the North Pacific, to the west of the coast of California, and it can shift between $28^{\circ} \mathrm{N} / 130^{\circ} \mathrm{W}$ (in winter) and $38^{\circ} \mathrm{N} / 150^{\circ} \mathrm{W}$ (in summer). This high-pressure center is persistent all year round, and it is more intense during summer but weakens during winter as it moves (Reid et al. 1958, Castro et al. 2006). The second is a low-pressure center markedly settled over the continent, northeastern Baja California, during summer; this is a semi-permanent system with a wider range in seasonal variability (Reid et al. 1958). Both systems are responsible for the northwesterly winds occurring during the warm months of the year.

\section{Todos Santos Bay}

There is a sea breeze circulation system in TSB, but this system is dominated by the circulation of synoptic winds blowing in a southeastern direction parallel to the coast of the Baja California Peninsula (Álvarez 1977, Parés 1981, Pavía and Reyes 1983). Two circulation systems were identified by

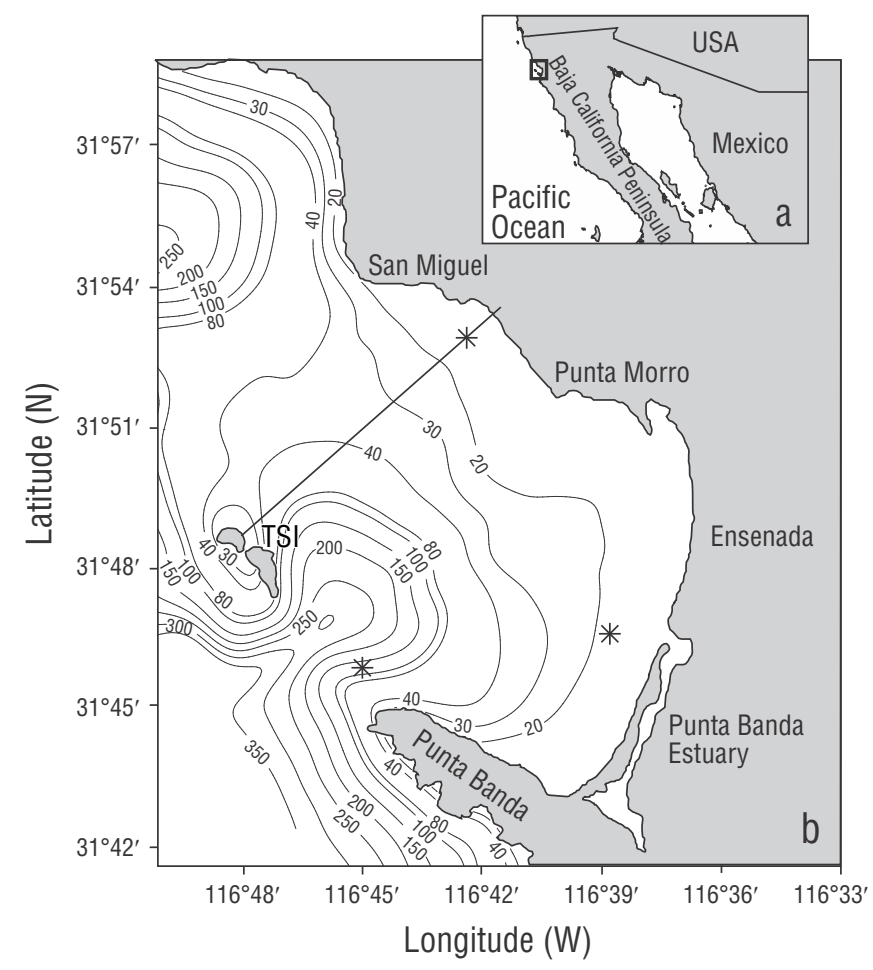

Figure 1. Study area: (a) Todos Santos Bay and (b) detailed view of the bay and bathymetry smoothed in ETOPO1. The asterisks represent the points on the grid where sea level time series were constructed. TSI stands for Todos Santos Island.

Figura 1. Área de estudio: (a) ubicación de la bahía de Todos Santos y (b) detalle de la bahía y la batimetría suavizada de ETOPO1. Los asteriscos indican los puntos de malla donde se construyeron las series de tiempo de la elevación del nivel del mar. TSI significa isla de Todos Santos.

ecuador, la corriente costera superficial estacional (CCS) y la contracorriente subsuperficial (CSS) que viaja al norte (Lynn y Simpson 1987). La CC es la parte oriental del giro anticiclónico del Pacífico Norte que se caracteriza por ser superficial $(0-300 \mathrm{~m})$. La CC transporta agua con alto contenido de oxígeno disuelto, baja temperatura y baja salinidad desde la región polar hasta la zona ecuatorial. La velocidad promedio de la $\mathrm{CC}$ es típicamente menor que $25 \mathrm{~cm} \cdot \mathrm{s}^{-1}$ (Reid y Schwartzlose 1962).

Estudios geostróficos (Lynn y Simpson 1987, Strub y James 2000) mostraron que, en primavera y verano, la CCS fluye hacia el ecuador en la región frente a California y la parte norte de la península de Baja California (a partir de $30^{\circ} \mathrm{N}$ ). Durante otoño e invierno, la CCS se invierte cerca de la costa. En contraste, la CSS fluye hacia el norte con velocidades de entre 4 y $8 \mathrm{~cm} \cdot \mathrm{s}^{-1}$ durante la mayor parte del año a una profundidad de $\sim 200 \mathrm{~m}$ (Barton y Argote 1980). La formación de la CCS se atribuye a múltiples frentes de surgencias locales (Strub y James 2000). Estudios numéricos mostraron que, para el desarrollo de los núcleos de velocidad de la CCS y CSS, es necesario estimar la variabilidad meridional del parámetro de Coriolis $f$ (plano $\beta$ ) y la componente 
a numeric study, forced with the CCS and stationary wind, for the summer circulation in TSB: the internal system, corresponding to the shallow section of the bay, and the external system, corresponding to the deep section of the bay. The external system consists of an intense, southward flowing current and it is limited by the $35-\mathrm{m}$ isobath. The internal system has 2 circulation structures. The first structure consists of an anticyclonic circulation that covers the entire bay and produces a large eddy. This eddy grows and splits, originating the second structure, which consists of 2 eddies circulating in opposite directions and of which the original anticyclonic eddy is limited to the northern portion of the bay. This process occurs approximately every 3 to 5 days. The circulation variability was attributed to variations in transport at the mouths of the bay due to eddies occurring outside TSB (Mateos et al. 2009).

Filonov et al. (2014) identified a current amplification and attenuation pattern with a 3-day period from current observations during 2007, and it was consistent with the numeric study described by Mateos et al. (2009). However, Filonov et al. (2014) did not find the same circulation pattern found in the numeric study for the area near San Miguel; measurements revealed a predominant northwestern direction, whereas the model revealed a southeastern direction. The circulation oscillations observed from measurements and numeric studies have not been explained. The main objective of this study is to analyze the mechanisms that could explain this variability. To accomplish this, we analyzed the outputs of a tridimensional and baroclinic numeric model, with high horizontal and vertical resolution, forced with non-stationary wind, heat fluxes, and the CCS.

\section{MATERIALS AND METHODS}

The Regional Ocean Modeling System (ROMS) used for this experiment was developed by the University of California at Los Angeles, Rutgers University, and the Research Institute for French Development (IRD, French acronym). The ROMS 3.6 version used for this study is managed by Rutgers University; its code can be obtained at https://www.myroms.org/. ROMS is a tridimensional freesurface model that uses vertical $\mathrm{S}$ coordinates and horizontal curvilinear coordinates. It solves momentum equations with hydrostatic approximations and the temperature and salinity equations, and it uses a state equation that correlates pressure, temperature, and salinity with density.

The horizontal boundary conditions were imposed on the the temperature, salinity, and velocity fields. For computational efficiency reasons, ROMS solves momentum equations using a split time scheme (external and internal modes), which requires a special treatment and coupling between the barotropic (fast) and baroclinic (slow) modes. The free surface and vertically integrated momentum equations are calculated in a finite number of barotropic time steps within each baroclinic time step. In the two- and three-dimensional a lo largo de la costa del esfuerzo del viento. El efecto $\beta$ permite la propagación de ondas libres (e.g., ondas de Rossby) hacia fuera de la costa, lo que modifica la estructura de densidad y contribuye a la formación de un gradiente de presión a lo largo de la costa que ayuda a la generación de la CSS a lo largo de la frontera este (Batten 1997). Frente a la costa norte de Baja California, entre $31^{\circ} \mathrm{N}$ y $32^{\circ} \mathrm{N}$, la CCS y la CSS son inestables y ocasionan gran variabilidad en la región (Mateos et al. 2013). Se ha encontrado que la variabilidad de la circulación frente a la costa norte de Baja California tiene un impacto sobre la variabilidad de la circulación dentro de la BTS (Mateos et al. 2009).

\section{Atmósfera}

Existen 2 sistemas relevantes que regulan la estacionalidad de los vientos a lo largo de las costas de California y Baja California, los cuales actúan en conjunto. El primero es un centro de alta presión que se localiza en el Pacífico Norte, al oeste de las costas de California, y puede oscilar entre $28^{\circ} \mathrm{N} / 130^{\circ} \mathrm{W}$ (en invierno) y $38^{\circ} \mathrm{N} / 150^{\circ} \mathrm{W}$ (en verano). Este centro de alta presión es persistente durante todo el año, y se intensifica en verano y debilita en invierno a medida que se desplaza (Reid et al. 1958, Castro et al. 2006). El segundo es un centro de baja presión que se establece de forma muy marcada durante el verano en el continente, al noreste de Baja California; este sistema es semipermanente, con un rango más amplio de variación estacional (Reid et al. 1958). Ambos sistemas son la causa de los vientos del noroeste en los meses cálidos del año.

\section{La bahía Todos Santos}

En la BTS se desarrolla un sistema de circulación de brisa marina, pero este sistema es dominado por la circulación de los vientos sinópticos paralelos a la costa de la península de Baja California con dirección al sureste (Álvarez 1977, Parés 1981, Pavía y Reyes 1983). En un estudio numérico sobre la circulación en la BTS en verano, forzado con el SCC y con viento estacionario, se identificaron 2 sistemas de circulación: el interior, correspondiente a la parte somera de la bahía, y el exterior, correspondiente a la parte profunda de la bahía. El sistema exterior consiste en una corriente intensa hacia el sur y está limitado por la isóbata de los $35 \mathrm{~m}$. El sistema interior oscila en 2 estructuras de circulación. La primera estructura consiste en una circulación anticiclónica que abarca toda la bahía y produce un gran remolino. Este remolino evoluciona, se divide y da origen a la segunda estructura, la cual consiste en 2 remolinos que giran en sentido opuesto y de los cuales el remolino anticiclónico original queda limitado a la parte norte de la bahía. Este proceso ocurre aproximadamente cada 3 a 5 días. Este comportamiento en la variabilidad de la circulación se atribuyó a la variación del transporte en las bocas de la bahía debido al paso de los remolinos en el exterior de la BTS (Mateos et al. 2009). 
equations, a third-order finite-differences approximation is adopted for the predictor (Leap-Frog) and corrector (AdamsMolton), which is robust and stable (Shchepetkin and McWilliams 2005). On the horizontal coordinate, the model discretizes equations over a grid in curvilinear orthogonal coordinates, for implementations in Cartesian, polar, and spherical coordinates. On the vertical coordinate, equations are discretized over a changing topography using vertical coordinates that follow the topography (generalized "S" coordinates).

All model forcings and configurations were built based on climatologies, except wind stress, which was treated as described by Mateos et al. (2013). The daily wind stress and heat flux data were obtained from the North America Regional Reanalysis with a spatial resolution of $32 \mathrm{~km}$.

The initial conditions and daily forcings in the open boundaries were obtained from a previous model validated by Mateos et al. (2013). The formerly mentioned model was executed with 2 nested grids. The parent grid was compared with previous studies that analyzed observations with different techniques and spatiotemporal resolutions (Barton and Argote 1980, Gómez-Valdez 1983, Espinosa-Carreón et al. 2012). The child grid was compared with one-year measurements carried out by deep-water mooring. The initial and boundary conditions were taken from the child grid outputs.

This study has higher horizontal and vertical resolution than the experiment presented by Mateos et al. (2013). Thus, a grid was constructed with $170 \times 340$ cells on the horizontal coordinate, with an average resolution of $150 \mathrm{~m}$, and 30 sigma levels were used on the vertical coordinate. In addition, a baroclinic time step set to $30 \mathrm{~s}$ was used to avoid violating the Courant condition due to increased resolution.

\section{RESUlts}

Temperature and elevation of sea level fields for August were analyzed. The sea level elevation monthly average (Fig. 2) showed water accumulation in the region between Ensenada and the Punta Banda Estuary (E-PBE). Average water level decreased towards the northern mouth of the bay, with a $0.5-\mathrm{cm}$ average difference between the mouth and the E-PBE region. In general, mean cyclonic circulation was observed covering the entire bay at $5 \mathrm{~m}$ depth (Fig. 2). This current pattern is consistent with the subtidal currents obtained from 2 high-frequency radars (Flores-Vidal et al. 2015). The mean subtidal current field showed that observed magnitudes were lower than $5 \mathrm{~cm} \cdot \mathrm{s}^{-1}$, which is consistent with the model. Flores-Vidal et al. (2015) attribute the subinertial current behavior in the bay to the effects of the synoptic currents and/or to the synoptic wind field. Another important feature found in mean flow are 2 cyclonic eddies in TSB and a cyclonic circulation at the mouth close to TSI.

Instant elevation fields showed that water accumulation in the southern region of the bay was released within approximately 3 to 5 days. For example, the evolution for sea level
Filonov et al. (2014) realizaron observaciones de corrientes durante el verano de 2007 e identificaron un patrón de amplificación y atenuación de las corrientes con periodo de 3 días, congruente con lo descrito en el estudio numérico de Mateos et al. (2009). Sin embargo, cerca de San Miguel no observaron el patrón de circulación encontrado en el estudio numérico; con las mediciones, la dirección predominante fue al noroeste, mientras que con el modelo la dirección fue al sureste. Las oscilaciones de la circulación observadas con mediciones y en estudios numéricos no han sido explicadas. El presente estudio tiene como objetivo principal analizar los mecanismos que pueden explicar esta variabilidad. Para ello, se analizaron las salidas de un modelo numérico tridimensional y baroclínico, con alta resolución horizontal y vertical, forzado con viento no estacionario, flujos de calor y el SCC.

\section{MATERIALES Y MÉTODOS}

Para este experimento numérico, se utilizó el modelo Regional Ocean Modeling System (ROMS, por sus siglas en inglés) desarrollado por la Universidad de California de Los Ángeles, la Universidad de Rutgers y el Instituto de Investigación para el Desarrollo de Francia (IRD, siglas en francés). Para fines de este estudio, se utilizó la versión 3.6 del ROMS, la cual administra la Universidad de Rutgers y cuyo código puede ser obtenido a través de la página en internet https:// www.myroms.org/. El ROMS es un modelo de superficie libre tridimensional que usa coordenadas $\mathrm{S}$ en la vertical y coordenadas curvilíneas en la horizontal. El ROMS resuelve las ecuaciones de momento con la aproximación hidrostática y las ecuaciones de temperatura y salinidad, y usa una ecuación de estado que relaciona a la presión, la temperatura y la salinidad con la densidad.

Las condiciones de frontera en la horizontal fueron impuestas en los campos de temperatura, salinidad y velocidad. Por razones de eficiencia computacional, el modelo ROMS resuelve las ecuaciones de momento usando un esquema de paso de tiempo dividido (modo externo e interno), el cual requiere un tratamiento especial y acoplamiento entre los modos barotrópicos (rápido) y baroclínicos (lento). La superficie libre y las ecuaciones de momento verticalmente integradas son calculadas en un número finito de pasos de tiempo barotrópicos dentro de cada paso de tiempo baroclínico. En las ecuaciones bidimensionales y tridimensionales se adopta una aproximación de diferencias finitas de tercer orden para el predictor (Leap-Frog) y el corrector (Adams-Molton), el cual es robusto y estable (Shchepetkin y McWilliams 2005). En la horizontal, el modelo discretiza las ecuaciones sobre una malla en coordenadas ortogonales curvilíneas, lo que permite aplicaciones en coordenadas cartesianas, polares y esféricas. En la vertical, las ecuaciones son discretizadas sobre una topografía variable usando coordenadas verticales que siguen la topografía (coordenadas "S" generalizadas). 


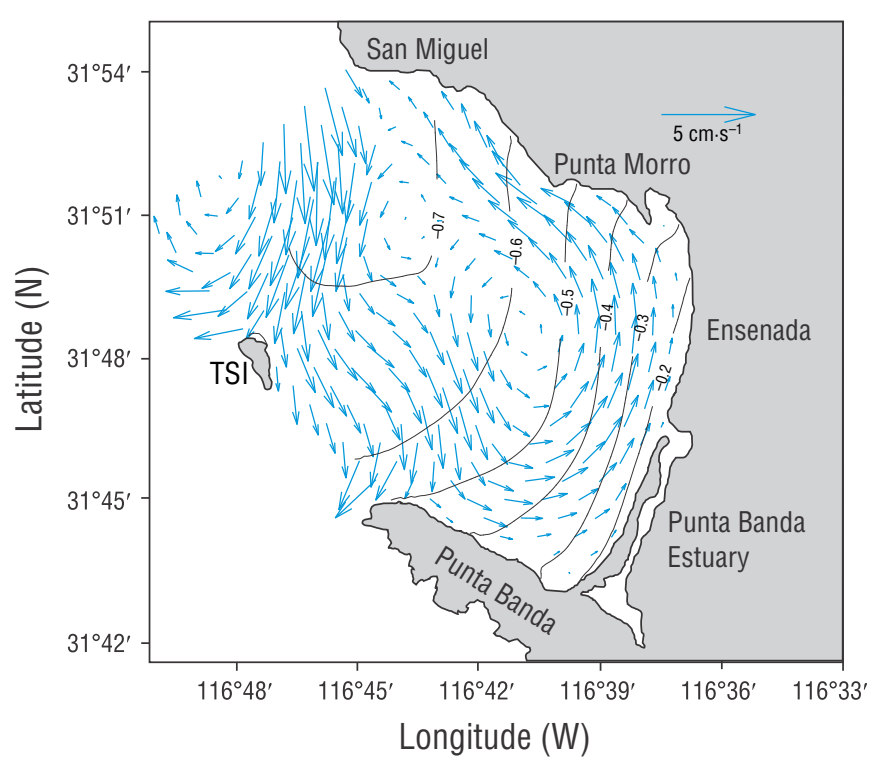

Figure 2. Average sea level elevation (isolines, centimeters) and current velocity at $5 \mathrm{~m}$ depth for August. An increased rise in sea level towards the south is shown.

Figura 2. Elevación promedio del nivel del mar (isolíneas, centímetros) y velocidad de las corrientes a $5 \mathrm{~m}$ de profundidad para agosto. Se observa un aumento en la elevación del nivel del mar hacia el sur.

and instant velocity fields at $5 \mathrm{~m}$ depth were shown for 2 and 5 August (Fig. 3a, c, respectively). In addition, to elucidate on the vertical structure, a vertical temperature section is shown for the area close to the northern mouth (Fig. 1), down to $20 \mathrm{~m}$ depth, during these 2 days (Fig. 3b, d). On 2 August, the sea level structure (Fig. 3a) was very similar to the mean structure; elevation was highest in the section located in the E-PBE region and decreased towards the northern mouth of TSB. The velocity field showed a cyclonic eddy at the center of TSB and an anticyclonic one to the north. The latter, prevented the outward flow of water through San Miguel. On the vertical scale, the temperature structure was almost homogenous. The $6{ }^{\circ} \mathrm{C}$ isotherm rose from $14 \mathrm{~m}$ near TSI up to the surface at the coast, forming a horizontal front with an approximate difference of $4{ }^{\circ} \mathrm{C}$ in $7 \mathrm{~km}$. As expected, due to the conditions, current velocities in TSB had a strong barotropic component (not shown).

For 5 August maximum elevations were found along the west coast and decreased towards the western mouth of TSB (Fig. 3c). On the other hand, sea level decreased by almost $0.3 \mathrm{~cm}$ in the E-PBE region, whereas in the San Miguel-Punta Morro region sea level increased by approximately $0.7 \mathrm{~cm}$. The velocity field showed 2 anticyclonic eddies that covered almost all of TSB. The cyclonic eddy observed on day 2 at the northern mouth of TSB moved westward. Also, a small anticyclonic eddy ( $\sim 2-\mathrm{km}$ diameter) was observed to the south of Punta Morro. The layout of the previously mentioned eddies favored the outward flow from
Todos los forzamientos y la configuración del modelo fueron construidos a partir de climatologías, excepto el esfuerzo del viento, que se trató de la misma manera que lo hicieron Mateos et al. (2013). Los datos diarios del esfuerzo del viento y los flujos de calor se obtuvieron del modelo North American Regional Reanalysis con una resolución espacial de $32 \mathrm{~km}$.

Las condiciones iniciales y los forzamientos diarios en las fronteras abiertas fueron obtenidas de un modelo previamente validado por Mateos et al. (2013). El modelo anteriormente mencionado se ejecutó con 2 mallas anidadas. Se comparó la malla madre con estudios previos dónde se analizaron observaciones con diferentes técnicas y resoluciones espaciotemporales (Barton y Argote 1980, GómezValdez 1983, Espinosa-Carreón et al. 2012). La malla hija se comparó con mediciones de un año realizadas en un anclaje profundo. Las condiciones iniciales y de frontera fueron tomadas de las salidas de la malla hija.

A diferencia del experimento numérico presentado por Mateos et al. (2013), el presente trabajo tiene una mayor resolución horizontal y vertical. Entonces, en la horizontal se construyó una malla de $170 \times 340$ celdas, con una resolución promedio de $150 \mathrm{~m}$, y se utilizaron 30 niveles sigma en la vertical. También, dado el aumento de la resolución, para no violar la condición de Courant, se empleó un paso de tiempo baroclínico de $30 \mathrm{~s}$.

\section{RESUltados}

De los resultados obtenidos, se analizaron los campos de temperatura y elevación del nivel del mar para agosto. En el promedio mensual de la elevación del nivel del mar (Fig. 2) se aprecia acumulamiento de agua en la región entre Ensenada y el estero de Punta Banda (E-EPB). El nivel del agua promedio disminuyó hacia la boca norte de la bahía, con diferencia promedio de $0.5 \mathrm{~cm}$ entre la boca y la región E-EPB. En términos generales, se observó una circulación media ciclónica que abarcó toda la bahía, a $5 \mathrm{~m}$ de profundidad (Fig. 2). Este patrón de corrientes medias es consistente con las corrientes submareales, obtenidas con 2 radares de alta frecuencia (Flores-Vidal et al. 2015). Según el campo medio de las corrientes submareales obtenido mediante las observaciones, las magnitudes fueron inferiores a $5 \mathrm{~cm} \cdot \mathrm{s}^{-1}$, congruente con lo modelado. Flores-Vidal et al. (2015) atribuyen el comportamiento de las corrientes subinerciales en la bahía a los efectos de las corrientes sinópticas y/o al campo del viento sinóptico. Otro rasgo importante encontrado en el flujo medio son 2 remolinos ciclónicos al interior de la BTS y la circulación ciclónica en la boca norte pegado a la ITS.

En los campos instantáneos de elevación se observó que la acumulación de agua en la región sur de la bahía se liberó entre aproximadamente 3 y 5 días. Por ejemplo, para el 2 y 5 de agosto se mostraron la evolución del nivel del mar y los campos de velocidad instantáneos a $5 \mathrm{~m}$ de profundidad (Fig. 3a, c, respectivamente). Adicionalmente, para dilucidar sobre la estructura vertical, se muestra un transecto vertical 

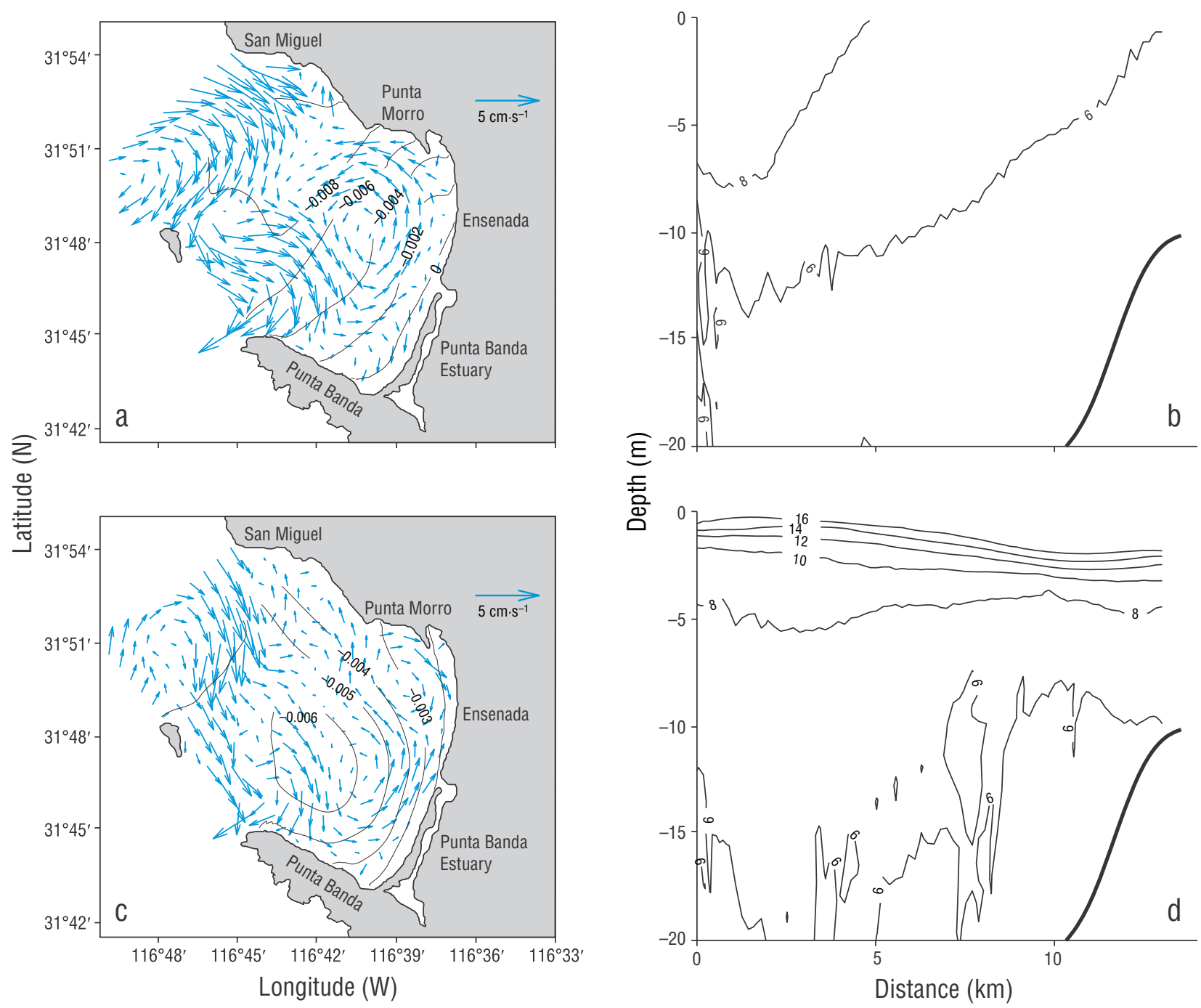

Figure 3. Sea level elevation and wind fields and instantaneous temperature sections at 2 different times. Sea level elevation (m) and the associated velocity field are shown for 2 August (a) and 5 August (c). The temperature $\left({ }^{\circ} \mathrm{C}\right)$ vertical section is shown for 2 August $(\mathbf{b})$ and 5 August (d), and the section goes from Todos Santos Island to the coast off San Miguel.

Figura 3. Campos de elevación del nivel del mar, campos de velocidad y cortes de temperatura instantáneos a 2 tiempos distintos. La elevación del nivel del mar (m) y el campo de velocidad asociado se muestran para el 2 de agosto (a) y el 5 de agosto (c). El corte vertical de la temperatura $\left({ }^{\circ} \mathrm{C}\right)$ se muestra para el 2 de agosto (b) y el 5 de agosto (d); la sección va desde la isla Todos Santos hasta la costa cerca de San Miguel.

TSB through San Miguel. The vertical temperature section shows that the water column was well stratified in the upper $5 \mathrm{~m}$. Isotherms at the surface decreased towards the coast (warm water close to the shore). Unlike day 2, day 5 had an important baroclinic component, which was also observed in the velocity field (not shown).

Additionally, the vertical transects for the western mouth were plotted for the same days ( 2 and 5) that were previously analyzed (not shown). The western mouth of TSB reached depths greater than $300 \mathrm{~m}$. A similar stratification behavior as the one seen in the northern mouth was observed. However, for day 2 , the homogenous layer was only $5 \mathrm{~m}$ deep. de temperatura, cercano a la boca norte (Fig. 1), hasta los $20 \mathrm{~m}$ de profundidad para los mismos días mencionados anteriormente (Fig. 3b, d). Para el 2 de agosto, la estructura del nivel del mar (Fig. 3a) fue muy similar a la estructura media; la parte más elevada se localizó en la región E-EPB y decreció hacia la boca norte de la BTS. El campo de velocidad mostró la presencia de un remolino ciclónico al centro de la BTS y uno anticiclónico al norte. Este último impidió la salida del flujo en San Miguel. La estructura de la temperatura fue casi homogénea en la vertical. La isoterma de los $6{ }^{\circ} \mathrm{C}$ se elevó desde los $14 \mathrm{~m}$ cerca de la ITS hasta la superficie en la costa, formando un frente horizontal con diferencia 
For each one of the 3 grid points in the bay (Fig. 1, asterisks), sea level time series were constructed considering the same criteria. The first was located to the south of San Miguel, the second at the western mouth of TSB, and the third off Punta Banda Estuary (not shown). The linear tendency was removed from the time series, so values ranged around zero. In general, without removing the linear tendency, sea level was lower off San Miguel than off Punta Banda Estuary (not shown). The sea level time series showed that when sea level decreased off Punta Banda Estuary and at the western mouth, sea level increased off San Miguel (Fig. 4a). The Pearson correlation between the time series for Punta Banda Estuary and San Miguel was $-0.76(P=1.14 \times$ $\left.10^{-6}\right)$, whereas for the western mouth and San Miguel it was $-0.54(P=0.001)$; thus, the null hypothesis, which states that the 2 series have no correlation, was rejected for both comparisons. For elevation of sea level, the Pearson correlation between the western mouth and Punta Banda Estuary was $0.26(P=0.15)$, so the null hypothesis $(95 \%$ confidence interval) was not rejected.

To determine the effect of wind, a time series for the wind-stress (used by the model) component parallel to the coast (San Miguel-Ensenada) was plotted for the same points considered in the sea level time series (Fig. 4b). The correlation between wind stress and sea level elevation was 0.95 $\left(P=1.9 \times 10^{-15}\right)$ and $-0.83\left(P=1.3 \times 10^{-8}\right)$ for San Miguel and Punta Banda Estuary, respectively.

A complex empirical orthogonal function (CEOF) analysis was applied to the sea level elevation data corresponding to August. This analysis is a modification to the empirical orthogonal functions (EOF), and consists in adding a quadrature function as a complex number to the data. Thus, the real part is the original data and the Hilbert transform is the complex part.

The CEOF analysis for elevation of sea level showed that the first 2 modes explained close to $87 \%$ of the variance. The first CEOF mode (Fig. 5) explained $66.5 \%$ of the variance. In the spatial structure (Fig. 5a), relatively higher elevation was observed for the Punta Banda Estuary region, and the central and southern parts of the bay. A depression in sea level was observed off Ensenada and at the western mouth of TSB. The phase (Fig. 5b) showed propagation of elevation from the Punta Banda Estuary region to the northern mouth of the bay. The temporal structure of the mode (Fig. 5c) showed peaks of approximately 3 days, similar to what was found in measurements (data) by spectral analysis of sea level and currents (Filonov et al. 2014).

The second CEOF mode (Fig. 6) explained $20.3 \%$ of the variance in the elevation field for August. In the spatial structure (Fig. 5a), differently to what was observed in the first mode, the highest relative elevations were found in the western mouth of the bay and off Ensenada. The lowest elevations were found in the area off Punta Banda Estuary and the central part of the bay. The propagation of elevation went from the western mouth of the bay towards the coast of Ensenada de aproximadamente $4{ }^{\circ} \mathrm{C}$ en $7 \mathrm{~km}$. Como era de esperarse, ante este escenario, las velocidades en la BTS tuvieron una fuerte componente barotrópica (no mostrada).

La elevación del nivel del mar para el 5 de agosto (Fig. 3c) mostró las máximas elevaciones a lo largo de la costa oeste, y disminuyó hacia la boca oeste de la BTS. Por otro lado, la elevación del nivel del mar disminuyó cerca de $0.3 \mathrm{~cm}$ en la región E-EPB, mientras que en la región de San Miguel-punta Morro el nivel aumentó aproximadamente $0.7 \mathrm{~cm}$. El campo de velocidad mostró 2 remolinos anticiclónicos que abarcaron casi toda la BTS. El remolino ciclónico observado el 2 de agosto en la boca norte de la BTS se desplazó hacia el oeste. Además, se observó un remolino anticiclónico pequeño ( $\sim 2 \mathrm{~km}$ de diámetro) al sur de punta Morro. La disposición de los remolinos anteriormente mencionados favoreció la salida del flujo de la BTS por punta San Miguel. El transecto vertical de temperatura mostró que la columna de agua estuvo bien estratificada en los primeros $5 \mathrm{~m}$ de profundidad. Las isotermas en la superficie descendieron hacia la costa (agua cálida pegado a la costa). A diferencia del día 2 de agosto, el día 5 tuvo una componente baroclínica importante que se reflejó en los campos de velocidad (no mostrado).

Adicionalmente, se graficaron los transectos verticales de la boca oeste, para los mismos días ( 2 y 5 ) analizados anteriormente (no mostrado). Esta boca de la BTS alcanzó profundidades superiores a los $300 \mathrm{~m}$. Se observó un comportamiento similar en la estratificación al observado para la boca norte, pero, en el día 2, la capa homogénea llegó sólo a los $5 \mathrm{~m}$ de profundidad.

Para cada uno de los 3 puntos de malla de la bahía (Fig. 1, indicados con asteriscos), se construyeron series temporales del nivel del mar considerando los mismos criterios. El primero, se localizó al sur de San Miguel, el segundo en la boca oeste de la BTS y el tercero frente al estero de Punta Banda. A las series temporales se les quitó la tendencia lineal, por lo que oscilaron alrededor del cero. En general, sin quitar la tendencia lineal, la elevación del nivel del mar en San Miguel fue menor que frente al estero de Punta Banda (no mostrado). Las series temporales para la elevación del nivel del mar mostraron que cuando el nivel del mar disminuyó frente al estero de Punta banda y en la boca oeste, en San Miguel dicho nivel aumentó (Fig. 4a). La correlación de Pearson entre las series temporales para punta Banda y San Miguel fue de $-0.76\left(P=1.14 \times 10^{-6}\right)$, mientras que para la boca oeste y San Miguel fue de $-0.54(P=0.001)$, lo que significa que, en ambas comparaciones, se rechazó la hipótesis nula que dice que no están correlacionadas las series. Para la elevación del nivel del mar, la correlación de Pearson entre la boca oeste y punta Banda fue de $0.26(P=0.15)$, por lo que no se rechazó ( $95 \%$ de confianza) la hipótesis nula.

Para conocer el efecto del viento, se graficó la serie temporal de la componente paralela a la costa (San MiguelEnsenada) del esfuerzo del viento, empleado por el modelo, para los mismos puntos que la serie temporal de la elevación 

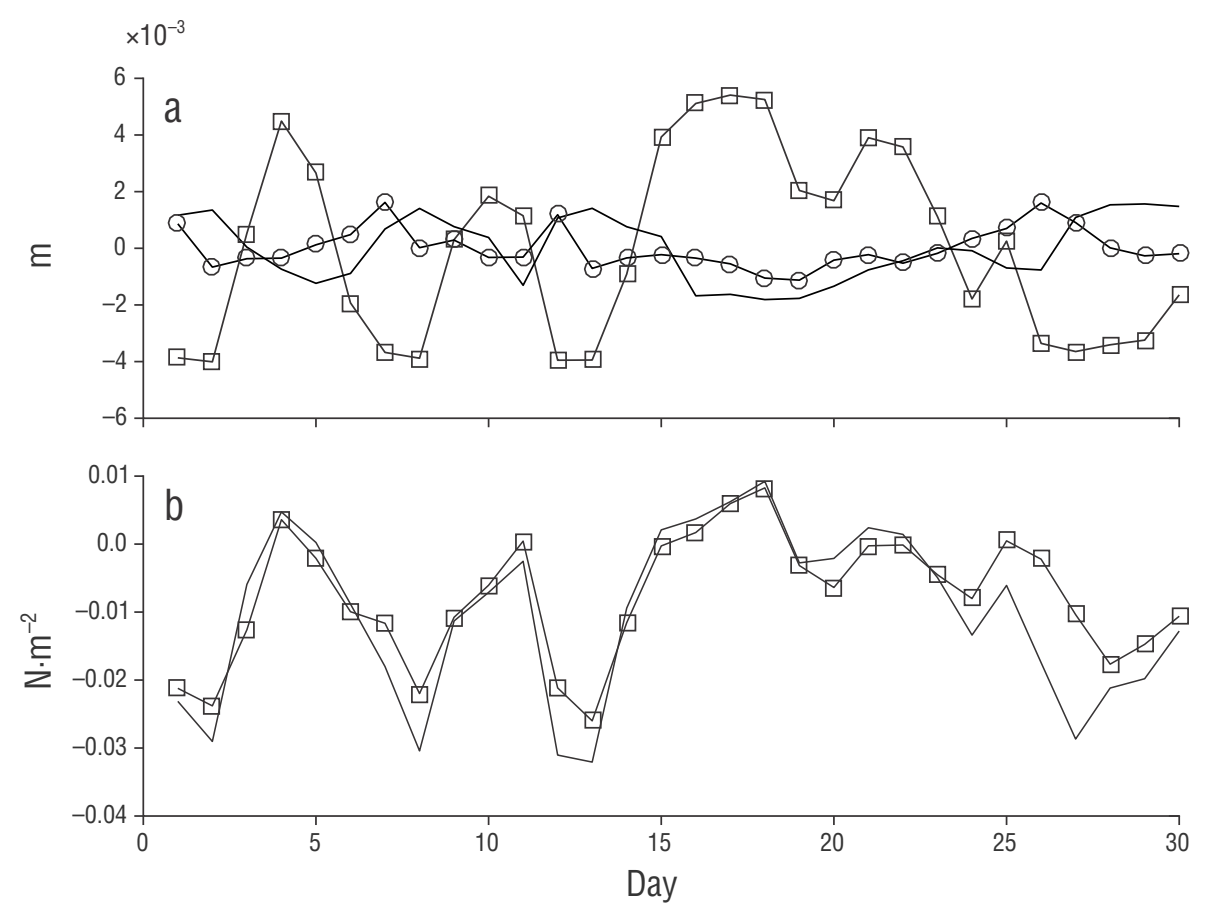

Figure 4. Time series of elevation of sea level (with no linear tendency) (a) and the wind stress component parallel to the coast (San Miguel-Punta Morro) (b) for the sites in Figure 1: the site close to San Miguel (empty squares), the western mouth of Todos Santo Bay (empty circles), and the site near Punta Banda Estuary (continuous line).

Figura 4. Series de tiempo de la elevación del nivel del mar (sin tendencia lineal) (a) y el componente del esfuerzo del viento paralelo a la costa (San Miguel-punta Morro) (b) en los sitios indicados en Figura 1: el punto ubicado cerca de San Miguel (cuadro vacío), la boca oeste de la bahía de Todos Santos (círculo vacío) y el punto cercano al estero de Punta Banda (línea continua).

(Fig. 6b). On the other hand, the temporal structure for this mode (Fig. 6c) showed peaks of approximately 5 days. However, 2 or 3-day peaks were identified at the end of the month.

\section{DISCUSSION}

The results show evidence that wind, mainly southeasterly winds, caused water transport to the southeastern part of the bay. As a result, sea level in the E-PBE region increased, since Punta Banda Estuary forms a water flux barrier. Moreover, off the San Miguel-Punta Morro coasts, upwelling of cold water occurred because of the southward water transport. This is consistent with what was reported in previous studies (Mateos et al. 2009). Due to upwelling of cold water in the San Miguel-Punta Morro region, coastal water flux is expected to move southeast (as seen in Mateos et al. 2009). In this study, water velocity in the San Miguel-Punta Morro region showed a northeastern direction, similar to what was found from measurement studies (Filonov et al. 2014). This suggests that the numerical experiment with stationary wind favors geostrophy, which considerably modifies the mean velocity field in the bay.

The results suggest that changes in sea level modify the temperature vertical structure and horizontal velocity fields. del nivel del mar (Fig. 4b). La correlación entre el esfuerzo del viento y la elevación del nivel del mar fue de $0.95(P=$ $\left.1.9 \times 10^{-15}\right)$ y $-0.83\left(P=1.3 \times 10^{-8}\right)$ para San Miguel y el estero de Punta Banda, respectivamente.

Se realizó un análisis de funciones empíricas ortogonales complejas (FEOC) a los datos de elevación del nivel del mar correspondientes al mes de agosto. Este análisis es una modificación al de las funciones empíricas ortogonales (FEO), y consiste en añadir una función de cuadratura como un número complejo a los datos. Por tanto, los datos originales son la parte real y el resultado de la transformación de Hilbert de los datos originales es la parte compleja.

El análisis de FEOC para la elevación del nivel del mar mostró que los primeros 2 modos explicaron cerca del $87 \%$ de la varianza. El primer modo (Fig. 5) del FEOC explicó el $66.5 \%$ de la varianza. En la estructura espacial (Fig. 5a) se observó una elevación relativa mayor en la región del estero de Punta Banda, centro y sur de la bahía. Frente a Ensenada y en la boca oeste de la BTS, se observó una depresión en el nivel del mar. La fase (Fig. 5b) mostró la propagación de la elevación desde la región del estero de Punta Banda hasta la boca norte de la bahía. La estructura temporal del modo (Fig. 5c) mostró picos de aproximadamente 3 días, similar a lo encontrado con las mediciones mediante análisis espectrales de la elevación y las corrientes (Filonov et al. 2014). 

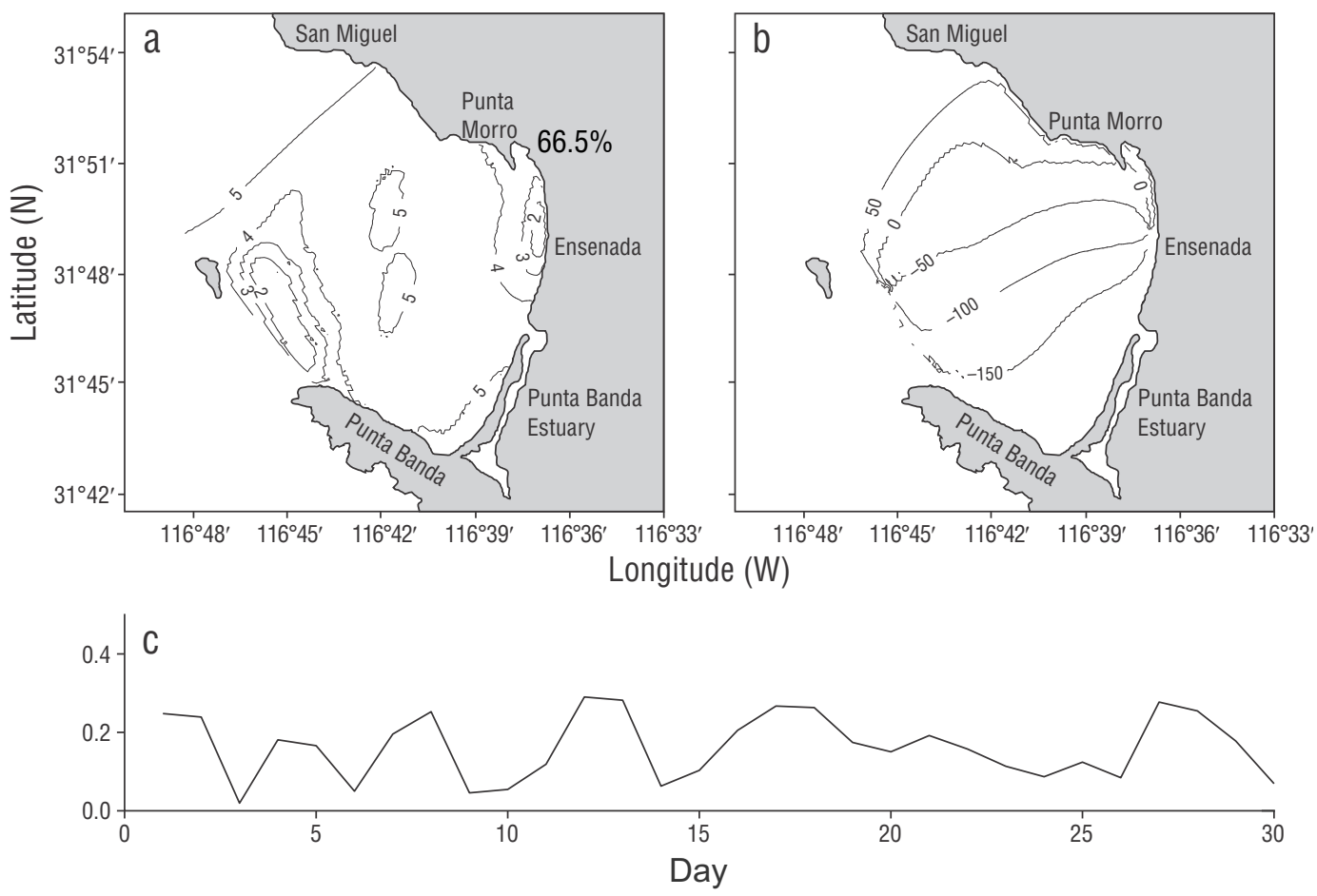

Figure 5. First mode of the complex empirical orthogonal function analysis of elevation of sea level for August, which explains $66.5 \%$ of the variance: (a) spatial structure of elevation amplitude normalized with variance, (b) spatial structure of the phase (each outline represents $50^{\circ}$ ), and (c) temporal structure of the mode.

Figura 5. Primer modo del análisis de funciones empíricas ortogonales complejas de la elevación del nivel del mar para agosto, que explica el $66.5 \%$ de la varianza: (a) estructura espacial de la amplitud de la elevación normalizada con la varianza, (b) estructura espacial de la fase (cada contorno representa $50^{\circ}$ ) y (c) estructura temporal del modo.

These changes in sea level occur in the same periodicity (3-5 days) as that for the reported variations in the velocity fields (Mateos et al. 2009, Filonov et al. 2014), suggesting that water accumulation release in the E-PBE region causes this variability.

The high correlation between elevation of sea-level and wind-stress $(0.95$ and -0.86$)$ indicates that the intensification and weakening of the wind lead to the accumulation and release of water in E-PBE, respectively. However, in the previous numeric study, which was forced with stationary wind, water release was observed to occur with a similar periodicity. This is due to the fact that the numeric study was forced with CCS, as was done in the present study. Variability occurring in CCS is also associated with variability in wind stress (Strub and James 2000); that is, data on wind variability is included in CCS in both experiments.

The EOF analysis confirmed the propagation (release) to south of the free surface (elevation of sea level) towards the northwest of the bay, explaining $66.5 \%$ of the variability. On the other hand, the second mode $(20.3 \%)$ suggests that free sea-surface variability in TSB is partly due to disturbances in the external part of the bay. This is consistent with the correlation found between elevations of the western mouth of TSB and San Miguel. Furthermore, the lack of correlation between
El segundo modo (Fig. 6) del FEOC explicó el 20.3\% de la varianza del campo de elevación de agosto. En la estructura espacial (Fig. 5a), a diferencia del primer modo, las mayores elevaciones relativas se ubicaron en la boca oeste de la bahía y frente a Ensenada. Las elevaciones menores se ubicaron en la zona cercana al EPB y centro de la bahía. La propagación de la elevación fue de la boca oeste de la bahía hacia la costa de Ensenada (Fig. 6b). Por otro lado, la estructura temporal de este modo (Fig. 6c) mostró picos de aproximadamente 5 días. Sin embargo, se presentaron picos de 3 o 2 días al final del mes.

\section{Discusión}

Los resultados obtenidos muestran evidencias de que el viento, principalmente hacia el sureste, fue la causa del transporte de agua hacia el sureste de la bahía. Como resultado, el nivel del mar en la región E-EPB se incrementó debido a que el EPB forma una barrera al flujo de agua. Además, frente a la costa San Miguel-punta Morro se presentó una surgencia de agua fría por el transporte de agua hacia el sur. Lo anterior concuerda con lo reportado en estudios anteriores (Mateos et al. 2009). Al existir un afloramiento de agua fría en San Miguel-punta Morro, se espera que el flujo pegado a la costa 

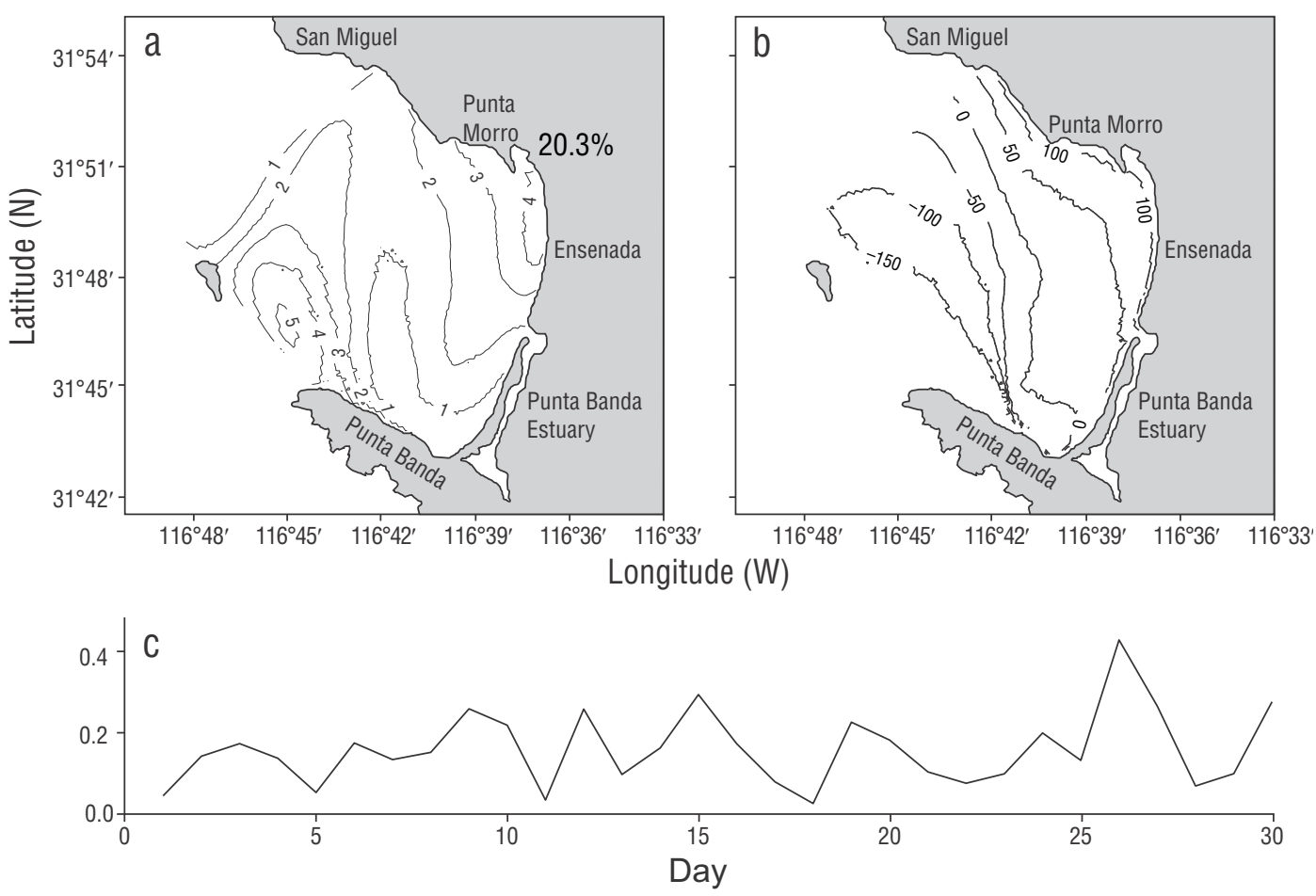

Figure 6. Second mode of the complex empirical orthogonal function analysis of elevation of sea level for August, which explains $20.3 \%$ of the variance: (a) spatial structure of elevation amplitude normalized with variance, (b) spatial structure the phase (each outline represents $50^{\circ}$ ), and (c) temporal structure of the mode.

Figura 6. Segundo modo del análisis de funciones empíricas ortogonales complejas de la elevación del nivel del mar para agosto, que explica el 20.3\% de la varianza: (a) estructura espacial de la amplitud de la elevación normalizada con la varianza, (b) estructura espacial de la fase (cada contorno representa $50^{\circ}$ ) y (c) estructura temporal del modo.

the western mouth and Punta Banda suggests different mechanisms that modify the temperature vertical structure off San Miguel. Disturbances in the external part of the bay can explain the variability reported in the study using stationary wind (Mateos et al. 2009).

This study correlates variability of velocity fields with sea level changes. The accumulation of water in the E-PBE region was caused by water transport from the northern part of the bay driven by wind-stress. Water accumulation is released every 3 to 5 days and propagates as a wave towards the northern part of the bay, modifying the velocity field and thermal structure at TSB. The periodicity of wave propagation is a result of the weakening of local winds and disturbances in the external part of TSB.

\section{AKNOWLEDGMENTS}

This study was financed through the National Council for Science and Technology (Mexico), project 182574 to EM, and the IMTA and CICESE regular funds. We thank the anonymous reviewers for their valuable comments.

English translation by Claudia Michel-Villalobos. en esa zona sea hacia el sureste (como en Mateos et al. 2009). En este estudio se observó que la velocidad en la zona San Miguel-punta Morro tuvo dirección al noreste, similar a lo encontrado con las mediciones (Filonov et al. 2014). Esto sugiere que el experimento numérico con viento estacionario favorece la geostrofía, lo cual modifica considerablemente el campo medio de velocidad al interior de la bahía.

Los resultados apuntan a que los cambios en la elevación del nivel del mar modifican la estructura vertical de la temperatura y el campo horizontal de velocidad. Estos cambios en la elevación del nivel del mar ocurren con la misma periodicidad (3-5 días) que las variaciones de los campos de velocidad reportadas (Mateos et al. 2009, Filonov et al. 2014), sugiriendo que la liberación de acumulación de agua en la EEPB es la causa de tal variabilidad.

La correlación tan alta entre la elevación del nivel del mar y el esfuerzo del viento $(0.95$ y -0.86$)$ refleja que la intensificación y relajación del viento conducen, respectivamente, al acumulamiento y a la liberación de agua en la E-EPB. Sin embargo, en el estudio numérico previo, el cual fue forzado con viento estacionario, también hay liberación del agua acumulada con una periodicidad similar. Esto último es debido a que el experimento numérico fue forzado con el SCC, de la 


\section{REFERENCIAS}

Álvarez L. 1977. Vientos en la Bahía de Todos Santos, Baja California. Cienc. Mar. 4(1): 81-89.

Argote-Espinoza ML, Gavidia-Medina FJ, Amador-Buenrostro A. 1991. Wind-induced circulation in Todos Santos bay, B.C., Mexico. Atmósfera 4: 101-115.

Barton ED, Argote ML. 1980. Hydrographic variability in an upwelling area off northern Baja California in June 1976. J. Mar. Res. 38(4): 631-649.

Batten ML. 1997. Wind-forced modeling studies of currents, meanders, and eddies in the California Current system. J. Geophys. Res. 102(C1), 985-1010.

Castro R, Mascarenhas A, Martínez-Díaz-de-León A, Durazo R, Gil-Silva G. 2006. Spatial influence and oceanic thermal response to Santa Ana events along the Baja California Peninsula. Atmósfera 19(3): 195-211.

Espinosa-Carreón TL, Gaxiola-Castro G, Beier E, Strub PT, Kurczyn JA. 2012. Effects of mesoscale processes on phytoplankton chlorophyll off Baja California. J. Geophys. Res. 117(C4): C04005. http://dx.doi.org/10.1029/2011JC007604

Filonov A, Lavín M, Ladah LB, Tereshchenko I. 2014. Spatial variability of internal waves in an open bay with a narrow steep shelf in the Pacific off NW Mexico. Continental Shelf Research, 78: $1-15$ https://dx.doi.org/10.1016/j.csr.2014.01.015

Flores-Vidal X, Durazo R, Castro R, Navarro LF, Dominguez F, Gil E. 2015. Fine-scale tidal and sub-tidal variability of an upwelling-influenced bay as measured by the Mexican High Frequency Radar Observing System. In: Coastal Ocean Observing Systems: Advances and Syntheses (ISBN: 9780128020227), Elsevier. https://doi.org/10.1016/B978-0-12-802022-7.00012-2

Gavidia F. 1988. Simulación numérica de la circulación barotrópica en la Bahía de Todos Santos, Baja California. Tesis de Maestria, CICESE.

Gómez-Valdez J. 1983. Estructura hidrográfica promedio frente a Baja California. Cienc. Mar. 9(2): 75-86.

Lynn RJ, Simpson JJ. 1987. The California current system: The seasonal variability of its physical characteristics. J. Geophys. Res. 92(C12): 12947-12966. http://dx.doi.org/10.1029/JC092iC12p12947

Mateos E, Marinone S, Parés-Sierra A. 2009. Towards the numerical simulation of the summer circulation in Todos Santos Bay, Ensenada, BC., México. Ocean Model. Online 27(1-2): 107-112. https://doi.org/10.1016/j.ocemod.2008.11.002

Mateos E, Marinone SG, Lavín MF. 2013. Numerical modeling of the coastal circulation off northern Baja California and southern California. Cont. Shelf Res 58: 50-66. https://doi.org/10.1016/j.csr.2013.02.008

Parés A. 1981. Análisis de componentes principales de los vientos superficiales sobre la Bahía de Todos Santos. BSc thesis. Universidad Autónoma de Baja California.

Pavía E, Reyes S. 1983. Variaciones espaciales y estacionales del Viento superficial en la Bahía de Todos Santos, BC. Cienc. Mar. 9(1): 151-167.

Reid Jl, Schwartzlose RA. 1962. Direct measurements of the Davison current off central California. J. Geophys. Res. 67(6): 2491-2497.

https://doi.org/10.1029/jz067i006p02491 misma manera que en esta investigación. La variabilidad del SCC a su vez está relacionada con las variaciones del esfuerzo del viento (Strub y James 2000); es decir, la información de la variabilidad del viento está incluida en el SCC en ambos experimentos.

El análisis por FEO confirma la propagación (liberación) al sur de la superficie libre (elevación del nivel del mar) hacia el noroeste de la bahía, explicando el $66.5 \%$ de su variabilidad. Por otro lado, el segundo modo (20.3\%) sugiere que una parte de la variabilidad en la superficie libre del mar, dentro de la BTS, se debe a las perturbaciones del exterior de la bahía. Esto es congruente con la correlación encontrada, para la elevación, entre la boca oeste de la BTS y San Miguel. Por otro lado, la falta de correlación entre la boca oeste y punta Banda sugiere mecanismos diferentes que modifican la estructura vertical de temperatura en San Miguel. Las perturbaciones del exterior de la bahía pueden explicar la variabilidad reportada en el estudio con viento estacionario (Mateos et al. 2009).

En este estudio se asocia la variabilidad de los campos de velocidad con los cambios en el nivel del mar. Se identificó que el acumulamiento de agua en la región E-EPB se debe al transporte de agua del norte de la bahía por efecto del esfuerzo del viento. El acumulamiento de agua es liberado cada 3 a 5 días y se propaga, como una onda, hacia el norte de la bahía, lo que modifica el campo de velocidad y la estructura térmica de la BTS. La periodicidad de la propagación de la onda es consecuencia de la relajación del viento local, y de las perturbaciones del exterior de la BTS.

\section{Agradecimientos}

Esta investigación fue financiada por el Consejo Nacional de Ciencia y Tecnología (México), a través del proyecto 182574 a cargo de EM, y por el fondo regular del IMTA y CICESE. Agradecemos a los revisores anónimos por sus comentarios críticos.

Reid JLJr, Roden GI, Wyllie JG. 1958. Studies of the California Current System. CalCOFI report, 27-56.

Shchepetkin AF, McWilliams JC. 2005. The regional oceanic modeling system (ROMS): a split-explicit, free-surface, topography-following-coordinate oceanic model. Ocean Model. Online 9(4): 347-404. https://doi.org/10.1016/j.ocemod.2004.08.002

Strub PT, James C. 2000. Altimeter-derived variability of the surface velocities in the California Current System: 2. Seasonal circulation and eddy statistics. Deep-Sea Res. (II Top. Stud. Oceanogr.) 47(5-6): 831-870. https://doi.org/10.1016/S0967-0645(99)00129-0

Received March 2017, Accepted June 2017. 